\title{
GPX1 wt Allele
}

National Cancer Institute

\section{Source}

National Cancer Institute. GPX1 wt Allele. NCI Thesaurus. Code C55289.

Human GPX1 wild-type allele is located in the vicinity of 3p21.3 and is approximately $12 \mathrm{~kb}$ in length. This allele, which encodes glutathione peroxidase 1 protein, is involved in detoxification of hydrogen peroxide. Variant alleles of GPX1 are associated with type 2 diabetes mellitus as well as certain types of cancer such as breast, lung and prostate cancer. 